\title{
The 'law of general application' requirement in expropriation law and the impact of the Expropriation Bill of 2015
}

\section{Bradley V Slade}

BComm LLM LLD

Senior Lecturer, Department of Public Law, University of Stellenbosch

\section{OPSOMMING}

Die 'algemeen geldende regsvoorskrif' vereiste in onteieningsreg en die implikasies van die Onteieningswetsontwerp van 2015

In hierdie artikel word die vereiste 'algemeen geldende regsvoorskrif' in artikel 25(2) van die Grondwet van die Republiek van Suid-Afrika,1996, ontleed aan die hand van die Onteieningswetsontwerp van 2015. Die relevante bepalings van die wetsontwerp laat blyk dat onteiening slegs geldig sal wees indien onteiening in wetgewing gematig word. Verder word dit duidelk gestel dat die onteieningsprosedure soos uiteengesit in die wetsontwerp gevolg moet word in alle gevalle waar eiendom onteien word, ongeag of die wetsontwerp of ander magtigende wet op gesteun word om die eiendom te onteien.

Die vereistes dat onteiening in wetgewing gemagtig moet word en dat die onteieningsprosedure in die wetsontwerp gevolg moet word, laat vrae onstaan oor die korrektheid van die toestaan van vergoeding vir 'n onteiening in gevalle waar daar geen magtiging vir die onteiening in die relevant wetgewing was nie, en waar daar ook geen formele onteieningsprosedure gevolg was nie.

Siende die toestaan van vergoeding vir onteiening in die toekoms slegs kan geskied in gevalle waar daar magtiging vir onteiening is en waar die onteieningprosedure gevolg was, blyk dit dat konstruktiewe onteiening nie toepassing kan vind in die Suid-Afrikaanse reg nie. Dit word gestel dat konstruktiewe onteiening slegs erken kan word in gevalle waar daar nie streng klem geplaas word op 'n statutêre basis vir onteiening nie. Daarom, indien die wetsontwerp in werking tree sal konstruktiewe onteiening nie toepassing kan vind in die Suid-Afrikaanse reg nie.

'[s]ince there is no common-law authority for expropriation in South African law, the law of general application that is required for expropriation by section 25(2) must specifically and clearly authorise an expropriation of property.'1

1 Van der Walt 'Property law in the constitutional democracy' 2017 Stell LR (forthcoming).

How to cite: Slade 'The 'law of general application' requirement in expropriation law and the impact of the Expropriation Bill of 2015,2017 De Jure 346-362 http://dx.doi.org/10.17159/2225-7160/2017/v50n2a8 


\section{Introduction}

Section 25(2) of the Constitution of the Republic of South Africa, 1996, requires an expropriation to be effected in terms of law of general application and undertaken for a public purpose or in the public interest. An expropriation must also be compensated, and the standard for the amount of compensation is that it must be just and equitable. While substantial research has been conducted on various issues relating to the public purpose or public interest requirement ${ }^{2}$ and the calculation of just and equitable compensation, ${ }^{3}$ the law of general application requirement has not received similar attention. Similarly, courts have considered issues surrounding public purpose or public interest ${ }^{4}$ and matters concerning compensation, ${ }^{5}$ but little, if any, attention has been paid to the law of general application requirement. ${ }^{6}$ In his last article, André van der Walt therefore correctly points out that the 'law of general application requirement' has 'arguably not received sufficient attention or rigorous enough analysis in case law. ${ }^{, 7}$

2 See Van der Walt Constitutional Property Law (2011) 458-503; Du Plessis 'Restitution of expropriated property upon non-realisation of the public purpose' 2011 TSAR 579-592; Van der Walt \& Slade 'Public purpose and changing circumstances: Harvey $v$ Umhlatuze Municipality and Others 2011 (1) SA 601 (KZP)' 2012 SALJ 219-235; Slade The Justification of Expropriation for Economic Development (LLD thesis 2012 US); Slade 'The less invasive means argument in expropriation law' 2013 TSAR 199-216; Slade 'Public purpose or public interest' and third party transfers' 2014 PER 166-206; Slade 'Addressing the issue in Harvey $v$ Umhlatuze Municipality in legislation' 2014 Stell LR 116-125; Mostert 'The poverty of precedent on public purpose/interest: An analysis of pre-constitutional an post-apartheid jurisprudence in South Africa' in Hoops et al (eds) Rethinking Expropriation Law Vol I (2015) 59-92.

3 Van der Walt (2011) 503-520; Badenhorst, Pienaar \& Mostert Silberberg and Schoeman's The Law of Property (2006) 568-578; Du Plessis Compensation for Expropriation under the Constitution (LLD thesis 2008 US).

4 On the less invasive means argument, see Bartsch Consult (Pty) Ltd $v$ Mayoral Committee of the Maluti-A-Phofung Municipality [2010] ZAFSHC 11, 4 February 2010; Erf 16 Bryntirion (Pty) Ltd v Minister of Public Works [2010] ZAGPPHC 154, 12 October 2010; Erf 16 Bryntirion (Pty) Ltd $v$ Minister of Public Works [2011] ZASCA 246, 1 December 2011. On the re-transfer of expropriated property on the non-realisation of the public purpose, see Harvey v Umhlatuze Municipality 2011 1 SA 601 (KZP). On the lawfulness of third party transfers see, eThekwini Municipality v Sotirios Spetsiotis [2009] ZAKZDHC 51, 6 November 2009; Bartsch Consult v Mayoral Committee of the Maluti-A-Phofung Municipality supra; Offit Enterprises (Pty) Ltd and Another $v$ Coega Development Corporation (Pty) Ltd 20095 SA 661 (SE); 2010 4 SA 242 (SCA); 20111 SA 293 (CC); Harvey v Umhlatuze Municipality supra.

5 Du Toit $v$ Minister of Transport 20061 SA 297 (CC); Haffejee $v$ eThekwini Municipality 20116 SA 134 (CC); Msiza v Director-General, Department of Rural Development and Land Reform 20165 SA 513 (LCC).

6 For instance, in Harvey $v$ Umhlatuze Municipality supra $\mathrm{n} 4$ at 82, the court referred to the two prerequisites for an expropriation in terms of the Expropriation Act 63 of 1975 as being public purpose and compensation, whilst not having regard to the constitutional requirement that it must be effected in terms of law of general application.

7 Van der Walt 2017 Stell LR (forthcoming). 
The Expropriation Act 63 of 1975, which currently governs expropriation law in South Africa, predates the Constitution by some 20 years. Therefore, it is not aligned with the constitutional provisions, especially section 25(2)-(3) that sets out the constitutional requirements for an expropriation. For instance, the Expropriation Act does not refer to a 'public interest' requirement, ${ }^{8}$ and the calculation of compensation is based primarily on the market value of the property. ${ }^{9}$ In terms of the Constitution, market value is but one factor in calculating just and equitable compensation. ${ }^{10}$ Attempts to repeal the 1975 Expropriation Act have twice been unsuccessful. Both the 2008 Expropriation Bill ${ }^{11}$ and the 2013 Expropriation Bill ${ }^{12}$ were retracted after receiving severe criticism. The 1975 Expropriation Act is set to be repealed by the 2015 Expropriation Bill. ${ }^{13}$ The Expropriation Bill aims to "ensure consistency with the Constitution and uniformity of procedure of all expropriations' ${ }^{14}$ The Bill, therefore, seeks to replace the primary expropriation act with one that is aligned with the constitutional requirements, in particular, section 25 (the property clause) and section 33(1), which provides for lawful, reasonable and procedurally fair administrative action.

Since the Expropriation Bill seeks alignment with the constitutional provisions and aims to streamline the expropriation procedure, it differs substantially from the current Expropriation Act. The Bill differs from the

8 In Offit Enterprises $v$ Coega Development Corporation supra 674 the high court held that the public interest requirement in the Constitution must be read in to the Expropriation Act to ensure compliance of the Act with the constitutional provisions.

9 S 12 of the Act dictates that the compensation to be awarded for the expropriation of property shall not exceed the market value plus an amount 'to make good any actual financial loss caused by the expropriation'. In $\mathrm{Du}$ Toit $v$ Minister of Transport supra par 36 the Court indicated that '[i]t would have been more expedient if the Legislature had made provision in the Act itself for complying with the constitutional standards of just and equitable compensation and ensuring that an equitable balance between the interests of the State and those of the individual is reflected.'

10 In Msiza $v$ Director-General supra the Land Claims Court held that although market value is a starting point to determine just and equitable compensation, it is not the most important factor; all the factors in s 25(3) must be given appropriate consideration. On the compensation provisions in the Expropriation Bill, see Van Wyk 'Compensation for land reform expropriation' 2017 TSAR 21-35.

11 On the Expropriation Bill B16-2008 [explanatory summary of Bill published in Government Gazette No 30963 of 11 April 2008] see Du Plessis 'The (shelved) Expropriation Bill B16-2008: An unconstitutional souvenir or an alarmist memento?' 2011 Stell LR 352-275; Pienaar 'Die grondwetlikheid van die voorgestelde onteieningsraamwerk vir Suid-Afrika' 2009 TSAR 344352; Van der Walt 'Constitutional property law' 2008 ASSAL 231-240.

12 On the 2013 Expropriation Bill GN 234 in GG 36269 of 20-03-2013, see Van der Walt 'Constitutional property law' 2013 ASSAL 216-220.

13 See https://pmg.org.za/bill/550/ (accessed 2017-04-04). The President referred the Bill back to the National Assembly because of reservations concerning inadequate public participation.

14 Memorandum on the Objects of the Expropriation Bill, 2015 par 1.3, http:// www.publicworks.gov.za/docswhitepapers.html (accessed 2017-04-04). 
Expropriation Act in the sense that it places greater emphasis on the statutory authority to expropriate. ${ }^{15}$ The Bill explicitly states that expropriation may only be effected if the use of the power of expropriation is authorised by legislation. ${ }^{16}$ In this regard, the Bill gives clearer guidance on the understanding of the law of general application requirement in section $25(2)$ that has been somewhat neglected in the literature and case law thus far. The Bill also requires an expropriation to be undertaken for a public purpose or public interest. The definition of public purpose in the Bill is similar to the definition currently in the Expropriation Act. ${ }^{17}$ The public interest definition in the Expropriation Bill is very similar to the definition of public interest in section 25(4) of the Constitution, ${ }^{18}$ although it does emphasise that reforms are necessary to bring about the equitable access to all South Africa's natural resources 'in order to redress the results of past racially discriminatory laws or practices'. ${ }^{19}$ The Bill also contains detailed provisions regarding the calculation and payment of compensation in line with the constitutional requirements in section $25(2)$ and (3). ${ }^{20}$

This article will, however, focus specifically on the law of general application requirement in section 25(2) of the Constitution and the implementation of this requirement in the Expropriation Bill. The purpose of this article is therefore to consider the authority to expropriate in more detail, with reference to the new Expropriation Bill and applicable case law. This article will also consider the implications the new Bill will have for the recognition of the doctrine of constructive expropriation in South African law.

\section{The Law of General Application Requirement and the Expropriation Bill}

Section 25(2) of the Constitution requires an expropriation to be effected in terms of law of general application. The current Expropriation Act is regarded as law of general application. ${ }^{21}$ Therefore, any expropriation effected in terms of this Act would satisfy the law of general application requirement in section 25(2) of the Constitution. However, the exact meaning of 'law of general application' is not clear from the Act and courts have not been able to give further guidance as to what would be

$15 \mathrm{~S} 2(1)$ of the Expropriation Act authorises the minister of public works to expropriate property in terms of the Act, but s 2(2) of the Act makes it clear that the minister may expropriate property in terms of $\mathrm{s}(1)$ or 'any other law'. The Act does not further indicate what is meant by the term 'law'.

16 See clause 2(3) and the discussion below.

17 '[P]ublic purposes' includes any purposes connected with the administration of the provisions of any law by an organ of State'.

18 S 25(4)(a) of the Constitution states that 'the public interest includes the nation's commitment to land reform, and to reform to bring about equitable access to all South Africa's national resources'.

19 Clause 1 of the Expropriation Bill.

20 Ch 5 of the Expropriation Bill

21 Offit Enterprises v Coega Development Corp supra (SE) 674. 
considered 'law of general application' in relation to expropriation disputes.

The 'law of general application' requirement has been considered, to some extent, in the context of the limitation of rights in terms of section 36(1) (the limitation clause) of the Constitution. Section 36(1) states that ' $[t]$ he rights in the Bill of Rights may be limited only in terms of law of general application ...' In theory, section 36(1) would be applied if there were a limitation of a right in the Bill of Rights. Therefore, if there has been a limitation of the right in section $25(2)$, the case proceeds to limitation analysis in terms of section $36(1) .{ }^{22}$ In relation to the law of general application requirement in section 36(1), the literature indicates that the limitation must be authorised by a law that was properly adopted', ${ }^{3}$ and the law must be of general application. ${ }^{24}$ Usually, a broad understanding of 'law' is accepted. The concept 'law' therefore includes original and delegated legislation, the rules of common law and customary law. ${ }^{25}$

However, the understanding of the 'law of general application' requirement specifically in expropriation cases is vastly different from the broader, more general understanding thereof in the broader constitutional context. ${ }^{26}$ Van der Walt points out that there is no common law authority for expropriation in South African law. 27 Therefore, because expropriation is regarded as a unique state power, it

22 However, see Slade 'Less invasive means: The relationship between sections 25 and 36 of the Constitution of the Republic of South Africa, 1996' in Hoops et al (eds) Rethinking Expropriation Law Vol I (2015) at 331348. On the general operation of the property clause in relation to the seminal constitutional property law decision in First National Bank of SA Ltd t/a Wesbank $v$ Commissioner, South African Revenue Service and Another; First National Bank of SA Ltd t/a Wesbank v Minister of Finance 20024 SA 768 (CC), see Van der Walt (2011) at 74-78. Even though the Court in First National Bank held that all expropriations are deprivations and therefore all limitations of property must comply with the requirements in terms of $\mathrm{s}$ 25(1) of the Constitution, the trend is to only have regard to the requirements in $\mathrm{s} 25(2)$ of the Constitution in cases where a formal expropriation has occurred. See in this regard, Du Toit $v$ Minister of Transport supra; Erf 16 Bryntirion $v$ Minister of Public Works supra; Slade (2015) at 340-341.

23 Van der Walt Property and Constitution (2012) at 28.

24 Currie \& De Waal The Bill of Rights Handbook (2013) 155; Van der Walt (2012) at 28.

25 Supra $\mathrm{n} 23$ at 156; Woolman \& Botha 'Limitations' in Woolman et al (eds) Constitutional Law of South Africa Vol II 2006 ch 34-7; S v Thebus 20036 SA 505 (CC) at parr 64-65.

26 See Van der Walt (2011) at 453; Van der Walt (2012) at 27. Gildenhuys Onteieningsreg (2011) 93 states that law authorising expropriation, would mostly be statutory law, although the author also provides an example of expropriation in terms of the common law.

27 Van der Walt (2011) at 453 with reference to Roux 'Property' in Cheadle et al (eds) South African Constitutional Law: The Bill of Rights 2010 ch 20. See also Van der Walt (2012) at 27. To the contrary, see Gildenhuys (2011) at 93. 
will always be carried out pursuant to legislation. ${ }^{28}$ This position is supported by the provisions of the Expropriation Bill of 2015, since the Bill requires the enabling legislation to specifically authorise a particular authority to acquire property through expropriation before it can be considered as such. Clause 2(3) of the Bill, which deals with the application of the Bill, states as follows:

An expropriating authority may expropriate property in terms of a power conferred on such expropriating authority by or under any law of general application, provided that the exercise of those powers is in accordance with sections 5 to 27 and 31 .

Although this clause refers to 'law of general application', it is clear from the Bill that the reference to 'law' is specifically restricted to legislation. In clause 1 of the Bill, an 'expropriating authority' is defined as 'an organ of state or a person empowered by this Act or any other legislation to acquire property through expropriation'. ${ }^{9}$ 'Expropriation', in turn, is defined as the 'compulsory acquisition of property'. 30

The requirement that an expropriating authority must be empowered by legislation before it can expropriate property is a departure from the position set out in both the 2008 and 2013 Expropriation Bills. In terms of the 2008 Bill, an expropriating authority was an organ of state that was empowered by the 'Act or any other law' to expropriate property. ${ }^{31}$ The 2013 Bill, on the other hand, referred to the relevant expropriating authorities being empowered by 'a law of general application' to expropriate property. ${ }^{32}$ Both the 2008 and 2013 Bill did not give greater clarity as to what is considered 'any other law' or 'a law of general application'. The 2015 Bill is, therefore, more specific in that it requires an expropriating authority to be empowered by legislation to expropriate property. Therefore, on a plain reading of clause 2(3) and the definitions identified above, an expropriating authority may only acquire property through expropriation if that expropriating authority is specifically empowered by legislation to expropriate property.

28 Van der Walt (2011) at 453. See Joyce \& McGregor $v$ Cape Provincial Administration 1946 AD 658 671, where the court stated that 'all rights of expropriation must rest upon a legislative foundation'. See further Jacobs \& Gildenhuys 'Expropriation in South Africa' in Erasmus (ed) Compensation for Expropriation: A Comparative Study Vol I 1990 at 373; Gildenhuys (2001) at 49 .

29 Own emphasis

30 This is in line with the Constitutional Court decision in Agri SA v Minister for Minerals and Energy 20134 SA 1 (CC) par 48 where the Court held that 'expropriation entails state acquisition of the property'. See also Reflect-All 1025 CC v MEC for Public Transport, Roads and Works, Gauteng Provincial Government 20096 SA 391 (CC) par 64.

31 Ch 1 of the Expropriation Bill of 2008.

32 Ch 1 of the Expropriation Bill of 2013. 
Similar to the current Expropriation Act, ${ }^{33}$ the Expropriation Bill of $2015^{34}$ awards the minister of public works the power to expropriate property for a public purpose or in the public interest. The Expropriation Bill does not affect the validity of other pieces of legislation (also future legislation) that also confers expropriation powers. Therefore, other pieces of legislation may be relied upon to expropriate property. However, the other pieces of legislation must specifically authorise the use of expropriation to achieve a public purpose. The Expropriation Bill also dictates that all expropriations must comply with the procedural requirements set out in clauses 5 to 27 and 31.35

In light of the above, two important interrelated points become apparent. Firstly, legislation must specifically authorise an expropriation. The uncertainty about whether the common law can effect an expropriation of property should therefore disappear. The notion that legislation must specifically authorise an expropriation calls to question certain decisions where the courts, especially the Constitutional Court, have been prepared to award compensation for an expropriation even though there was no formal expropriation procedure in terms of enabling legislation. Secondly, regardless of the statute empowering an expropriation, the procedure set out in the Bill must be followed in order for an expropriation to be formally valid. In this regard, the Bill goes a long way in ensuring that a uniform expropriation procedure will be adopted by all expropriating authorities. The emphasis on statutory authority and a mandatory expropriation procedure would restrict the possibility of awarding compensation in cases where there is acquisition of property, but not through expropriation. This also holds implications for accepting the doctrine of constructive expropriation in South African law, since constructive expropriation can only be recognised if the formal authority to expropriate is not observed strictly. ${ }^{36}$ The implications of these two interrelated points, as identified here, are further teased out below.

\section{Legislation Must Specifically Authorise Expropriation: An Analysis of Case Law}

The Expropriation Bill of 2015, which is set to replace the current Expropriation Act of 1975 , will be the primary and overarching piece of legislation that will govern expropriation in South Africa. Similar to the Expropriation Act, the Expropriation Bill empowers the minister of public works to expropriate property. The Bill also recognises that expropriating

33 See $\mathrm{s} 2$ of the Act.

34 Ch 2 of the Expropriation Bill of 2015.

35 Clauses 5 to 27 deal with processes involved in investigating the suitability of the property to be expropriated, the manner and form of the notice of intention to expropriate, the notice of expropriation, and issues surrounding compensation. Clause 31 deals with transitional arrangements and savings.

36 Van der Walt (2011) at 354 
authorities other than the minister of public works may expropriate property if those authorities are specifically empowered by other legislation to expropriate property. ${ }^{37}$ Irrespective of whether property is expropriated in terms of the Bill or other empowering legislation, the procedure set out in the Bill must be applied. In this regard, the Bill provides detailed guidelines as to how the expropriation process is to be implemented by the relevant authority. The Bill also sets out how compensation is to be calculated if property has been expropriated in line with the requirements as set out in the Bill.

From the above, it is clear that only in cases where property is acquired through expropriation can compensation be awarded in terms of the Expropriation Bill. If property is acquired in terms of legislation that does not authorise the use of expropriation to acquire the property, and the expropriation process as set out in the Bill is not followed, the acquisition of property cannot be treated as an expropriation, and the compensation provisions in the Bill cannot apply. Therefore, an interference with property in the form of an acquisition of property in cases where there is no authority for the expropriation of such property cannot be challenged in terms of the Expropriation Bill (or section 25(2) of the Constitution). ${ }^{38}$

If legislation, therefore, causes the acquisition of property in the state, but there is no authority for the expropriation in the legislation, the acquisition cannot be regarded as an expropriation. Therefore, the validity of such an acquisition cannot be challenged with reference to the Expropriation Bill; it must be challenged in terms of the prohibition against the arbitrary deprivation of property in section 25(1) of the Constitution or in terms of the rules of administrative law. ${ }^{39}$ The confiscation and forfeiture of property is an example where property is acquired in terms of a regulatory framework and the validity of the interference is tested against the requirements for a valid deprivation of property in terms of section 25(1) of the Constitution. ${ }^{40}$ Therefore, in cases where legislation of a regulatory nature causes property to vest in the state, the validity would have to be considered in terms of section 25(1). In the absence of clear authority being granted to expropriate, courts will be unable to award compensation in terms of the Expropriation Bill.

37 This is made clear in the definition of 'expropriation authority' in ch 1 of the Expropriation Bill. An expropriating authority may expropriate property if empowered by 'this Act or any other legislation'.

38 Since the Expropriation Bill gives effect to $\mathrm{s} 25(2)$, the principles of subsidiarity dictates that the Expropriation Bill must be relied upon if an expropriation is challenged. S 25(2) can only be relied upon if the Bill's constitutionality is challenged. On subsidiarity, specifically in the constitutional property law context, see Van der Walt (2012) at 35-36.

39 See Van der Sijde Reconsidering the Relationship between Property and Regulation: A Systemic Constitutional Approach (LLD thesis 2015 US), who argues that a litigant can only rely on S 25(1) of the Constitution if the deprivation was not caused by administrative action.

40 See in this regard Van der Walt (2011) at 311-323. 
There are a few examples in case law where the courts have found that an expropriation did not (or could not) occur, since the relevant state department or minister did not have the necessary authority to expropriate. For instance, in Offit Enterprises (Pty) Ltd and Another $v$ Coega Development Corporation (Pty) Ltd and Others ${ }^{41}$ the high court held that the threat of expropriation for which the applicant sought injunction was not real, since the relevant authority did not have the power in terms of the Expropriation Act of 1975 or the Eastern Cape Land Disposal Act ${ }^{42}$ to expropriate property. When the case came before the Constitutional Court, the Court noted that without any formal expropriation procedure, the validity of any future threat of expropriation would have to be adjudicated in terms of section $25(1)$ of the Constitution. ${ }^{43}$ Similarly, the minority of the Constitutional Court in Tshwane City $v$ Link Africa ${ }^{44}$ held that the provisions in the Expropriation Act could not apply to the matter in question, since the legislation, namely section 22(1) of the Electronic Communications Act, ${ }^{45}$ does not authorise the expropriation of property. In this regard, the minority held that the impugned section authorised an arbitrary deprivation of property in conflict with section 25(1) of the Constitution.

However, there are other examples where the Constitutional Court specifically did not seriously consider the law of general application requirement (i.e. the statutory authority to expropriate) and had held that the compensation provisions in the Expropriation Act did apply. In these cases, there was no authority in the applicable legislation to expropriate property, but the Court nevertheless indicated that compensation may be awarded in terms of the Expropriation Act. The first case in point is the Constitutional Court's decision in Arun Property Development (Pty) Ltd $v$ Cape Town City. ${ }^{46}$

In Arun, the issue was whether the local authority was obliged to pay compensation to the appellant since the local authority acquired the land of the appellant through the operation of legislation. ${ }^{47}$ The appellant relied on section 28 of the Land Use Planning Ordinance (LUPO) ${ }^{48}$ to claim compensation for land that vested in the local authority. Section 28 of LUPO determines that ownership of any land that is required by the local authority upon approval of subdivision for public streets and public places based on the normal need arising from the subdivision, shall vest in the local authority without compensation. The appellant argued that since land in excess of those required for the 'normal need' also vested

4120095 SA 661 (SE) 666-667.

427 of 2000.

43 Offit Enterprises $v$ Coega Development Corporation supra (CC).

4420156 SA 440 (CC) par 92.

4536 of 2005 (as amended by the Electronic Communications Amendment Act 37 of 2007 and the Electronic Communications Amendment Act 1 of 2014).

4620152 SA 584 (CC).

47 Idem at 1.

4815 of 1985. 
in the local authority upon approval of the subdivision, it had a right to be compensated. The Constitutional Court awarded compensation on the basis that section 28 of LUPO causes an ex lege transfer of ownership that 'has the same effect as an expropriation'. 49 The Court, therefore, determined that the local authority is obliged to pay compensation in terms of section 26(1) of the Expropriation Act of 1975.

In this decision, the Constitutional Court did not rigorously interrogate the purpose of the law that caused the vesting of normal and excess land. The purpose of LUPO is to regulate orderly township development; it does not confer the power of expropriation to achieve any particular purpose. ${ }^{50}$ Section 28 of LUPO allows for development contributions, a regulatory measure that leads to acquisition of property without compensation. ${ }^{51}$ The Court seems to have accepted that since property that is in excess of the normal need vested in the local authority, the owner is entitled to compensation as determined in terms of the Expropriation Act since the section does not exclude compensation for the excess property. ${ }^{52}$

The provisions in the new Expropriation Bill as outlined above calls into question the appropriateness of awarding compensation in Arun. ${ }^{53}$ In this decision, the particular legislative provision did not confer the power of expropriation on the local authority in order to effect proper town planning. The legislative provision allows for the vesting of property in the local authority in cases where that property is required to provide a particular development with public streets and places. The vesting of property, in this case, is typically regarded as development contributions or exactions, which falls under the state's regulatory powers. ${ }^{54}$ The validity of such exactions is therefore determined in terms of section $25(1)$, which requires a deprivation to be non-arbitrary. ${ }^{55}$ It has been argued that the vesting of excess land was contrary to section 25(1), because the Court itself admitted that there is no relationship between the acquisition of the land in excess of the normal need and the purpose of creating public streets and places for the development. ${ }^{56}$ The court should, therefore, have determined the validity of the vesting of the excess land in terms of section 25(1), and should not have ordered compensation in terms of the Expropriation Act. In terms of section

49 Arun supra at par 73.

50 Slade 'Compensation for what? An analysis of the outcome in Arun Property Development (Pty) Ltd $v$ Cape Town City' 2016 PER 1-25.

51 Slade 2016 PER 12-18; Van der Walt (2011) 290-292, Singer Introduction to Property (2005) 736-737. On the interpretation of s 28 of LUPO, see also Marais and Maree 'At the intersection between expropriation law and administrative law: Two critical views on the Constitutional Court's Arun judgment' 2016 PER 1-54.

52 However, it is questionable whether the section permits the vesting of land in excess of the normal need.

53 See also Slade 2016 PER 1-25

54 Slade 2016 PER 1-25 at 12-15; Van der Walt (2011) 290-292.

55 Slade 2016 PER 1-25 at 12-15; Van der Walt (2011) 290-292.

56 Arun supra par 40. See also Slade 2016 PER 15. 
25(1), a court should declare an arbitrary deprivation unconstitutional. ${ }^{57}$ No provision is made for the payment of compensation in terms of section 25(1).

The second case in which the Constitutional Court applied the compensation provisions in the Expropriation Act without considering whether there is actual authority in legislation that authorises expropriation, is the majority decision in Link Africa. In Link Africa, the Court considered the constitutional validity of section 22 of the Electronic Communications Act. ${ }^{58}$ Section 22 (1) of the Act permits a licence holder to 'enter upon any land' for the purposes of constructing, maintaining, altering or removing an electronic communications network. Section $22(2)$ requires that regard must be had to 'applicable law' when any action is taken in terms of section 22(1). At issue was whether a licence holder has to obtain consent from the relevant landowner before such licence holder performs any of the actions in section 22(1) of the Act. The argument of the respondent was that if consent is not required, any action taken in terms of section 22 will be in conflict with section 25(1) of the Constitution in that it permits an arbitrary deprivation of property.

According to the majority, a licence holder can only perform the actions identified in section 22(1) if the licence holder has regard to the 'applicable law' as required in terms of section 22(2). In terms of the approach adopted by the majority, there are two sources of law that, if applied, would prevent any action taken in terms of section 22(1) from being considered arbitrary. The first is the law of servitudes. The Court argued that section 22 affords the licence holder a public servitude, which must be exercised with due regard to common law principles. In this regard, the holder of the servitude (the licence holder) must exercise the rights in terms of section 22(1) 'respectfully and with due caution'. 59 Therefore, the licence holder would have to consult with the owner of the property before any action is taken in terms of section 22(1). ${ }^{60}$ Apart from consulting with the owner regarding the exercise of the competencies in terms of the licence, the court also held that the common law requirement of compensation applies. With reference to Van Rensburg $v$ Coetzee ${ }^{61}$ the Court stated that in cases where a court grants a way of necessity, the servitude that is created without the landowner's consent is 'treated as a kind of expropriation' that is compensated. ${ }^{62}$ The compensation would be to counter the disadvantage suffered by the affected property owner. ${ }^{63}$

57 See the discussion below on remedies.

5836 of 2005 (as amended by the Electronic Communications Amendment Act 37 of 2007 and the Electronic Communications Amendment Act 1 of 2014).

59 Link Africa supra at par 143. See Van der Walt Servitudes (2016) 207-208 on the application of the law of servitudes in this decision.

60 Link Africa supra at par 154.

6119794 SA 655 (AD).

62 Link Africa supra at par 149.

63 Idem at par 149. 
However, the Court also referred to a second source of law that, if applied, prevents a finding of arbitrariness. The Court referred to section 3 of the Expropriation Act and held that the public law protection of compensation for expropriation by juristic persons other than the state found in the Expropriation Act also applies to action taken under section 22(1). ${ }^{64}$ The Court is not correct to apply section 3 of the Expropriation Act, since the section allows the minister of public works to expropriate property on request of a juristic person if that juristic person requires the property for a public purpose but is unable to acquire it on reasonable terms. ${ }^{65}$ In this decision there was no request made to the minister to expropriate property for public purposes. In Link Africa, the legislation allowed the licence holder to enter upon the property of another for purposes of carrying out various tasks related to the construction and maintenance of the telecommunication networks. While the minister of public works may be called upon to expropriate property in order to allow a third party to fulfil a public purpose, the relevant section of the Electronic Telecommunications Act that was challenged does not authorise the use of expropriation in any form to realise the purpose of construction and maintenance of telecommunication networks. In the event that legislation does not authorise expropriation to achieve a particular public purpose, the compensation provisions of the Expropriation Act should not apply. The minority's view that the Expropriation Act does not apply is in this regard the correct approach, and is supported by the provisions in the Expropriation Bill. The compensation provisions in the Expropriation Bill would not apply in cases where there is no specific authority to expropriate property and where the expropriation procedure in the Bill has not been followed.

The two decisions discussed above shows an emerging tendency on the part of the Constitutional Court to apply the compensation provisions in the Expropriation Act in cases where there is no authority in the legislation to expropriate property. In both Arun and Link Africa the legislation in question is regulatory in nature. The aim of LUPO is to 'regulate land use planning and to provide for matters incidental thereto.' 66 Similarly, the primary purpose of the Electronic Communications $\mathrm{Act}^{67}$ is to 'provide for the regulation of electronic communications in the Republic in the public interest'. ${ }^{68}$ In terms of the provisions in the Expropriation Bill, as discussed above, the courts will be unable to award compensation in cases where there is no authority in the legislation in question to expropriate. If there is no authority in legislation to compulsorily acquire property through expropriation, any acquisition of property that is caused by or permitted in legislation cannot be attacked by relying on the Expropriation Bill or section 25(2) of the

64 Idem at par 157.

65 See further Van der Walt 'Constitutional property law' 2016 ASSAL (forthcoming).

66 Long title of the Ordinance.

6736 of 2005.

$68 \mathrm{~S} 2$ of the Act. 
Constitution. If legislation, therefore, causes or permits the acquisition of property, but there is no authority to expropriate, the infringement of property should be attacked with reference to section 25(1). This would mean that compensation with reference to the Expropriation Bill cannot be awarded for the compulsory acquisition of property in cases where an expropriation is not specifically authorised by legislation.

\section{Implications for the Recognition of Constructive Expropriation}

As argued above, the Bill makes it clear that expropriation can only take place if an expropriating authority is specifically empowered in legislation to acquire property through expropriation. Furthermore, the Bill makes the expropriation procedure, as set out in the Bill, mandatory, irrespective of the legislation relied upon to expropriate property. The Expropriation Bill sets out three phases in the expropriation procedure. ${ }^{69}$ The first phase relates to the investigation and gathering of information as to the suitability of the property to be expropriated. ${ }^{70}$ The second phase relates to serving notice of expropriation on the owner of the property or the holder of an unregistered right in the property. ${ }^{71}$ The third phase relates to the notice of expropriation that must be served on the owner or holder of an unregistered right if the expropriating authority decides to expropriate the property. ${ }^{72}$ In the notice of expropriation, the expropriating authority must include the amount of compensation that is payable. ${ }^{73}$ Chapter 5 (clauses 12-20), deals with compensation for expropriation. Clause 12 of the bill sets out how compensation must be determined. Clause 12(1), which is similar to section 25(3) of the Constitution, states that ' $[\mathrm{t}]$ he amount of compensation to be paid to an expropriated owner or expropriated holder must be just and equitable reflecting an equitable balance between the public interest and the interests of the expropriated owner or expropriated holder.' The compensation provision in chapter 5 of the Bill would arguably only apply in cases where property has been expropriated, in other words in cases where legislation has been relied upon to expropriate property and if the expropriation procedure in the Bill has been adhered to. This may hold implications for the acceptance of the doctrine of constructive expropriation in South African law.

The acceptance of the doctrine of constructive expropriation has not been decided authoritatively in South African law. ${ }^{74}$ In Steinberg $v$ South

69 Supra n 10 at 21-35.

70 Ch 3 of Bill. See supra n 10 at 31-32.

71 Clause 7 of the Bill. See supra $n 10$ at 32-33.

72 Clause 8 of the Bill. See supra n 10 at 33-34.

73 Clause 8(3)(g) states that the amount of compensation is either 'the amount of compensation offered by the expropriating authority or agreed to by the expropriating authority and the owner and the holder of an unregistered right'.

74 Van der Walt (2011) 376. 
Peninsula Municipality ${ }^{75}$ the Supreme Court of Appeal raised the possibility of accepting constructive expropriation, but in the end it gave no definite answer as to whether it should be accepted. ${ }^{76}$ Constructive expropriation seems to operate in a so-called 'grey area' between deprivations in section 25(1) and expropriations in section 25(2) of the Constitution. $^{77}$ The doctrine of constructive expropriation would therefore only be recognised if the concepts deprivation and expropriation cannot be clearly distinguished from each other. ${ }^{78}$

Mostert argues that the "doctrine" of constructive expropriation should essentially serve to curb excessive exercise of the state's regulatory powers for the sake of the public interest. ${ }^{79}$ She argues that upon invoking the doctrine of constructive expropriation, a claimant would either be seeking enforcement of the compensation provision in section 25(2) or alternatively the invalidation of the excessive regulation in terms of section $25(1)$ of the Constitution. ${ }^{80}$ Constructive expropriation can, therefore, occur when a court transforms an excessive regulatory measure into an expropriation, thereby triggering the compensation provision in section $25(2)$ of the Constitution. ${ }^{81}$ It is argued that constructive expropriation can only be recognised in jurisdictions where either the formal authority for expropriation or state acquisition of property is not strongly emphasised. ${ }^{82}$ With regard to state acquisition, the Constitutional Court has held that ' $[\mathrm{t}]$ here can be no expropriation in circumstances where deprivation does not result in property being acquired by the state'. ${ }^{83}$ It would, therefore, seem as if state acquisition of property is required before a deprivation can be considered an expropriation that must be compensated. However, it would be incorrect to treat any infringement on property that also involves state acquisition of the property concerned as an expropriation. There are various examples where state acquisition of property by the state in terms a regulatory scheme is not treated as expropriation, but

7520014 SA 1243 (SCA).

76 On Steinberg supra and constructive expropriation see Van der Walt (2011) 377-381; Badenhorst, Pienaar \& Mostert (2006) 554-557.

77 Van der Walt (2011) 347.

78 Mostert 'The distinction between deprivations and expropriations and the future of the 'doctrine' of constructive expropriation in South African law' 2003 SAJHR 573 describes this particular reading as a 'disjunctive' reading of S 25(1) and (2).

79 Mostert 2003 SAJHR 569.

80 Idem at 569.

81 See Mostert 2003 SAJHR 569; Bezuidenhout Compensation for Excessive but otherwise Lawful Regulatory State Action (LLD thesis 2014 US) 57-58; Van der Walt (2011) 350; Badenhorst, Pienaar \& Mostert (2006) 553-554

82 Van der Walt (2011) 354; supra n 32 at 58. German law, for instance, require that a law must specifically authorise an expropriation and indicate the basis upon which compensation must be calculated. Therefore, constructive expropriation is not recognised in German law: See Van der Walt (2011) 366; Van der Walt Constitutional Property Clauses (1999) 146150.

Agri SA supra at par 59. 
whose legitimacy is determined with reference to section 25(1) of the Constitution. $^{84}$

Although expropriation involves state acquisition of property, the Bill makes it clear that there should also be express authority for that acquisition in the form of expropriation in the enabling legislation. Therefore, the Bill's emphasis on the statutory authority for an expropriation, as well as making the expropriation procedure set out in the Bill mandatory, may hold implications for the recognition of constructive expropriation in South African law. If it is accepted that constructive expropriation involves payment of compensation in cases where a regulatory measure imposes a severe burden on a particular property owner, the provisions in the Bill potentially makes the recognition of constructive expropriation impossible. In terms of the Bill, an expropriation that requires compensation would only come about when there is specific legislative authority for an expropriation in the legislation and where the expropriation procedure in the Bill has been followed. In cases where there is no legislative authority to expropriate property for a particular purpose, questions of expropriation and compensation do not surface.

Therefore, if regulatory legislation causes property to vest in the state and it is regarded as excessive by a court, the court should, as a first option, invalidate the acquisition or the legislation that causes the acquisition. The court would not be able to award compensation in terms of the Expropriation Bill or section 25(2) of the Constitution because the provisions in the Bill does not allow for that. If, however, the purpose of the law or the acquisition is important, and invalidation of the law would not be the best option, ${ }^{85}$ the court would have to develop another remedy that may involve some form of payment. This remedy can include the payment of equalisation payments, ${ }^{86}$ reading-in a compensation provision into the legislation that causes the deprivation, ${ }^{87}$ or awarding constitutional damages in terms of sections 38 and 172(1)(b) of the 1996 Constitution. ${ }^{88}$ Although the discussion about the appropriateness of alternative remedies is outside the scope of this article, it seems clear that the courts would not be able to award compensation for an expropriation of property in cases where the legislation does not specifically authorise the expropriation and where the expropriation procedure in the Bill has not been implemented. The incorporation of the doctrine of constructive expropriation into South African law, therefore, seems unlikely.

84 See the discussion above at 3. See further Van der Walt (2011) 290; 311-312.

85 Supra $\mathrm{n} 32$ at $42-52$.

86 Supra $\mathrm{n} 32$ at 129-209, Van der Walt (2011) 345-346, 367, Badenhorst, Pienaar \& Mostert (2006) 557-558.

87 Supran 32 at 239-250, 283.

88 Supra $\mathrm{n} 32$ at 250-280, 285-296. 


\section{Conclusion}

In this article, the law of general application requirement in section 25(2) of the Constitution has been considered in light of the applicable provisions in the new Expropriation Bill of 2015. It is argued that the law of general application requirement in section 25(2) is restricted to legislation. The Bill makes it clear, in clause 2(3) and the accompanying definitions in clause 1 , that property may only be acquired through expropriation if legislation specifically authorises the use of expropriation to achieve a particular public purpose. In this regard, there is no common law authority of expropriation. Furthermore, the expropriation procedure as set out in the Bill must be followed by all authorities that are granted expropriatory powers in terms of either the Expropriation Bill or other enabling legislation.

The effect of strictly requiring a legislative basis to expropriate property coupled with the mandatory expropriation procedure that must be followed would potentially restrict the courts' ability to award compensation for an apparent expropriation in property disputes. Courts would not be able to award compensation for the acquisition of property in cases where there was no legislation authorising expropriation and where the expropriation procedure as set out in the Bill has not been followed. This conclusion calls to question the Constitutional Court's decision in Arun, where the Court awarded compensation for an apparent expropriation, even though the legislation in question did not provide for expropriation and even though no expropriation procedure was adopted. If the Court was correct in treating the issue as a constitutional property issue, then the Court should have decided the case with reference to section 25(1). The Court seems to accept that since acquisition of property occurred, compensation must also follow. However, this view cannot be supported as it blurs the line between valid regulatory state interference with property that may involve acquisition of such property and expropriation. As indicated above, there are instances where valid regulatory state interference with property leads to the acquisition of property, but it is not treated as an expropriation, since expropriation is a unique state power only to be used in clearly circumscribed circumstances, and generally as a matter of last resort.

Strictly requiring a legislative basis for an expropriation also renders the acceptance of the doctrine of constructive expropriation unlikely in South African law. In terms of the doctrine of constructive expropriation, courts transform an excessive regulatory imposition of property into an expropriation that must be compensated, since invalidation of the regulation would not be expedient. However, if a legislative basis authorising expropriation is strictly required, courts will not be able to award compensation in terms of the Expropriation Bill or section 25(2) in cases where it is found that a necessary regulatory measure is excessive, since courts will not be able to decide whether an expropriation has taken place or not. 
The Expropriation Bill of 2015, which is set to replace the predemocratic Expropriation Act of 1975 goes a long way in complying with the constitutional requirements for an expropriation, especially those found in section 25(2) of the Constitution. Although certain aspects of the Bill are called into question, ${ }^{89}$ the Bill does provide greater clarity as to what is to be understood as 'law of general application'. Requiring expropriation to be expressly authorised by legislation should be welcomed as it potentially provides greater clarity as to when a particular dispute must be resolved with reference to expropriation law.

89 Supra n 10 at 21-35. 